\title{
UANG SASUDUIK DALAM SISTEM PERKAWINAN DI NAGARI SITUJUAH GADANG KECAMATAN SITUJUAH LIMO NAGARI KABUPATEN LIMA PULUH KOTA PROVINSI SUMATERA BARAT
}

\author{
Annisa Umulhusni, Siti Nur Fathoni \\ Fakultas Syari'ah dan Hukum, UIN Sunan Gunung Djati Bandung, Indonesia \\ E-mail: annisaumulhusni42@gmail.com
}

\begin{abstract}
Obligatory giving by a prospective bridegroom to a prospective bride in a marriage is only a dowry, as explained in Article 30 of the Compilation of Islamic Law. Whereas in traditional marriages in Nagari Situjuah Gadang Situjuah District Limo Nagari Lima Puluh Regency in West Sumatra Province, a man who is going to get married is not required to give dowry only but is also required to give sasuduik money. Sasuduik money is a gift that is required to be a man who will get married by giving the amount of money desired by his future wife and family. If the sasuduik money cannot be fulfilled by men, the marriage will be delayed or even canceled. The purpose of this research is to find out the marriage system; the origin and position of Sasuduik money in the marriage system; a review of Islamic law on the provision of money for men who will hold marriages in Nagari Situjuah Gadang Situjuah Limo Nagari District Lima Puluh Regency City of West Sumatra Province.
\end{abstract}

Keywords: Dowry, Marriage, Uang Sasuduik

\begin{abstract}
Abstrak
Pemberian wajib oleh calon mempelai pria kepada calon mempelai wanita dalam sebuah perkawinan hanyalah mahar, sebagaimana dijelaskan dalam Pasal 30 Kompilasi Hukum Islam. Sedangkan dalam perkawinan adat di Nagari Situjuah Gadang Kecamatan Situjuah Limo Nagari Kabupaten Lima Puluh Kota Provinsi Sumatera Barat, seorang laki-laki yang akan menikah tidak diwajibkan memberikan mahar saja namun juga diharuskan memberikan uang sasuduik. Uang sasuduik adalah pemberian yang diharuskan kepada laki-laki yang akan melangsungkan pernikahan dengan memberikan sejumlah uang yang diinginkan oleh calon istri dan pihak keluarganya. Apabila uang sasuduik tidak dapat dipenuhi oleh pihak laki-laki maka perkawinan akan tertunda bahkan batal.Tujuan penelitian ini adalah untuk mengetahui sistem perkawinan; asal usul dan kedudukan uang sasuduik dalam sistem perkawinan; tinjauan hukum Islam terhadap pemberian uang sasuduik bagi laki-laki yang akan melangsungkan pernikahan di Nagari Situjuah Gadang Kecamatan Situjuah Limo Nagari Kabupaten Lima Puluh Kota Provinsi Sumatera Barat.
\end{abstract}

Kata Kunci : Mahar, Perkawinan, Uang Sasuduik. 


\section{PENDAHULUAN}

Perkawinan yang dilakukan dalam Islam menimbulkan hak dan kewajiban bagi suami dan istri. Kewajiban suami terhadap istrinya salah satunya adalah memberikan mahar. Islam sangat memperhatikan dan menghargai kedudukan seorang wanita dengan memberikan hak kepadanya, diantaranya adalah hak untuk menerima mahar (maskawin). ${ }^{1}$ Mahar adalah pemberian dari calon mempelai pria kepada calon mempelai wanita, baik berupa barang, uang atau yang tidak bertentangan dengan hukum Islam. ${ }^{2}$ Imam Syafi'I mengatakan bahwa mahar adalah sesuatu yang wajib diberikan oleh seorang laki-laki kepada perempuan untuk dapat menguasai seluruh anggota badannya. ${ }^{3}$

Mahar yang harus ada dalam setiap perkawinan, tetapi mahar tidak masuk ke dalam rukun perkawinan, karena mahar tidak mesti disebut dalam akad perkawinan dan tidak mesti diserahkan pada waktu akad itu berlangsung. Dengan demikian, mahar itu termasuk ke dalam syarat perkawinan. ${ }^{4}$

Kewajiban pemberian mahar untuk perempuan ini berdasarkan firman Allah surat An-Nisa' ayat 4 :

“Berikanlah maskawin (mahar) kepada perempuan (yang kamu nikahi) sebagai pemberian dengan penuh kerelaan. Kemudian, jika mereka menyerahkan kepada kamu sebagian dari (maskawin) itu dengan senang hati, Maka terimalah dan nikmatilah perberian itu dengan senang hati". ${ }^{5}$

Ayat ini menjelaskan bahwa surat An-Nisa' ayat 4 diarahkan kepada suami untuk berikanlah kepada wanita-wanita yang telah kalian ikat dengan mahar suatu hibah (pemberian), sebagai perlambang kasih sayang yang mendasari hubungan kalian berdua. Pemberian tersebut sebagai petanda cinta dan eratnya hubungan, di samping jalinan yang seharusnya meliputi rumah tangga yang kalian bangun. ${ }^{6}$

Minangkabau merupakan daerah yang masih kental dengan adat kebudayaan yang hingga saat ini masih dijunjung tinggi dalam berbagai aspek kehidupan. Masyarakat Minangkabau tidak lepas dari adat yang telah ada dan ditetapkan salah satunya yang berlaku di Nagari Situjuah Gadang, Kecamatan Situjuah Limo Nagari, Kabupaten Lima Puluh Kota Provinsi Sumatera Barat. Ketentuan yang berlaku di Nagari Situjuah Gadang, Kecamatan Situjuah Limo Nagari, Kabupaten Lima Puluh

\footnotetext{
${ }^{1}$ Abdul Rahman Ghozali, Figh Munakahat, Cet ke-1 (Jakarta: Kencana, 2003), hal. 84

${ }^{2}$ Kompilasi hukum Islam, (Bandung: Fokusindo Mandiri, 2016), hal. 8

${ }^{3}$ Abdul Rahman Ghozali, Fiqh Munakahat Cet.1, (Jakarta: Kencana, 2003) hal.85

${ }^{4}$ Amir Syarifuddin, Hukum Perkawinan Islam di Indonesia antara Figh Munakahat dan Undangundang Perkawinan, Cet ke-3. (Jakarta: Kencana, 2009) hal. 61

${ }^{5}$ Kementrian Agama Republik Indonesia, Al-Qur'an dan Terjemah. (Bandung: Diponegoro, 2012) hal. 77

${ }^{6}$ Bahrun Abubakar dan Hery Noer Aly, Terjemah Tafsir Al-Maraghi Juz 4, (Semarang: Karya Toha Putra, 1993) hlm. 330
}

2 Jurnal Al-Ahwal Al-Syakhsiyyah : Jurnal Hukum dan Peradilan Islam 
Annisa Ummulhusni, Siti Nurfatoni, Uang SASUDUIK dalam Sistem Perkawinan di Nagari Situjauh

Kota, Provinsi Sumatera Barat dalam pelaksanaan perkawinan disamping diwajibkan membayar mahar juga diharuskan membayar sejumlah uang kepada mempelai wanita yang dinamakan dengan uang sasuduik. Pemberian ini diharuskan kepada laki-laki yang akan melangsungkan perkawinan yaitu dengan memberikan sejumlah uang yang diinginkan oleh calon istri dan pihak keluarganya. Dimana uang sasuduik ini jumlahnya lebih besar atau berlipat dari jumlah mahar.

Uang sasuduik yang akan diserahkan oleh laki-laki terhadap pihak perampuan harus diketahui dan disepakati terlebih dahulu oleh niniak mamak (ninik mamak) dari pihak perempuan, hal tersebut dilakukan dengan cara bermusyawarah untuk menetapkan suatu kemufakatan. Jadi, yang menetukan kesepakatan dari jumlah uang sasuduik yang akan diberikan kepada pihak perempuang adalah niniak mamak, setelah itu baru baru disepakati oleh kedua orang tua perempuan ${ }^{7}$.

Menurut adat Minangkabau khususnya di Nagari Situjuah Gadang, Kecamatan Situjuah Limo Nagari, Kabupaten Lima Puluh Kota, Provinsi Sumatera Barat uang sasuduik harus ada dalam suatu perkawinan. Namun, terkadang tingginya uang sasuduik membuat laki-laki keberatan dalam memberikan uang sasuduik, dan banyak juga terjadinya kawin lari akibat tidak dapat memenuhi uang sasuduik tersebut. ${ }^{8}$ Dalam hal ini, tidak ada ketentuan syariat Islam yang mengatakan bahwa harus ada uang sasuduik dalam perkawinan. Namun, yang terjadi di Nagari Situjuah Gadang, Kecamatan Situjuah Limo Nagari, Kabupaten Lima Puluh Kota, Provinsi Sumatera Barat menjadikan uang sasuduik sebuah keharusan yang harus ada untuk malangsungkan perkawinan.

\section{METODOLOGI}

Metode yang peneliti gunakan dalam penelitian ini adalah Metode Penelitan Deskriptif Analisis yaitu mendeskripsikan suatu analisis data lapangan secara utuh dari hasil pengamatan yang peneliti lakukan. Dalam hal ini mengenai tinjauan hukum Islam mengenai uang sasuduik dalam sistem perkawinan di Nagari Situjuah Gadang, Kecamatan Situjuah Limo Nagari, Kabupaten Lima Puluah Kota, Provinsi Sumatera Barat.

${ }^{7}$ Wawancara dengan salah seorang tokoh adat di Nagari Situjuah Gadang, Kecamatan Situjuah Limo Nagari, Kabupaten Lima Puluh Kota, Provinsi Sumatera Barat yaitu Datuak Rajo Malano Mudo pada tanggal 07 Januari 2019 Pukul 18:47

${ }^{8}$ Wawancara dengan salah seorang tokoh masyarakat di Nagari Situjuah Gadang, Kecamatan Situjuah Limo Nagari, Kabupaten Lima Puluh Kota, Provinsi Sumatera Barat yaitu Agung Maulana Dinata pada tanggal 05 Januari 2019 Pukul 19:39

Jurnal Al-Ahwal Al-Syakhsiyyah : Jurnal Hukum Keluarga dan Peradilan Islam 3 


\section{HASIL PENELITIAN DAN PEMBAHASAN}

Perkawinan atau pernikahan diambil dari dua kata, yaitu nikah (نكاح) dan zawaj (زواخ). Kata na-ka-ha banyak terdapat dalam Al-Qur'an dengan arti kawin, seperti dalam sarat an-Nisa' ayat 3 :

“Dan jika kamu khawatir tidak akan mampu berlaku adil terhadap (hak-hak) perempuan yatim (bilamana kamu menikahinya), Maka nikahilah perempuan (lain) yang kamu senangi: dua, tiga atau empat orang. Tetapi jika kamu khawatir tidak akan mampu berlaku adil, maka (nikahilah) seorang saja, atau hamba sahaya perempuan yang kamu miliki. Yang demikian itu lebih dekat agar kamu tidak berbuat zalim." 9

Akad suatu perkawinan sebagaimana akad-akad yang lainnya, akan tumbuh setelah akad tersebut hak dan kewajiban yang saling berhubungan. Adanya hak antara suami dan istri setelah akad pernikahan terjadi. Dasar dari hak-hak dan kewajiban yang timbul ini adalah tradisi yang berdasarkan kepada fitrah masing-masing seorang lakilaki dan seorang perempuan. Hak-hak keuangan yang harus dipenuhi oleh suami terhadapa istrinya adalah hak mahar, nafkah dan tempat tinggal. Sedangkan hak nonmateri atau kejiwaan adalah keadilan, kebaikan dalam perlakuan, pergaulan yang baik, taatnya seorang istri kepada suami dalam kebaikan, dan perlindungan istri dari berbagai jenis aniaya dan hinaan.

Mahar secara etimologi artinya maskawin. Secara terminologi, mahar ialah "pemberian wajib dari calon suami kepada calon istrinya sebagai ketulusan hati calon suami untuk menimbulkan rasa cinta kasih bagi seorang istri kepada calon suaminya. Atau bisa juga diartikan suatu pemberian yang diwajibkan bagi calon suami kepada calon istrinya, baik dalam bentuk benda maupun jasa. ${ }^{10}$

Dasar wajibnya menyerahkan mahar itu ditetapkan dalam al-Qur'an dan dalam hadist Nabi. Dalil dalam ayat al-Qur'an adalah firman Allah dalam surat al-Nisa' ayat 4 yang bunyinya :

“Berikanlah maskawin (mahar) kepada perempuan (yang kamu nikahi) sebagai pemberian dengan penuh kerelaan. Kemudian jika mereka menyerahkan kepada kamu sebagian dari (maskawin) itu dengan senang hati, Maka terimalah dan nikmatilah pemberian itu dengan senang hati" ${ }^{11}$

Karena mahar merupakan syarat sah nikah, bahkan Imam Malik mengatakannya sebagai rukun nikah, maka hukum pemberiannya adalah wajib. Mengenai kewajiban

\footnotetext{
${ }_{9}$ Kementrian Agama Republik Indonesia, Al-Qur'an dan Terjemah. (Bandung: Diponegoro, 2012) hal. 77

${ }^{10}$ Abdul Rahman Ghozali, Fiqh Munakahat, Cetakan ke-1 (Jakarta: Kencana, 2003) hal. 84

${ }^{11}$ Kementrian Agama Republik Indonesia, Al-Qur'an dan Terjemah. (Bandung: Diponegoro, 2012) hal. 77
}

4 Jurnal Al-Ahwal Al-Syakhsiyyah : Jurnal Hukum dan Peradilan Islam 
Annisa Ummulhusni, Siti Nurfatoni, Uang SASUDUIK dalam Sistem Perkawinan di Nagari Situjauh mahar, para fuqaha telah sepakat bahwa mahar wajib diberikan oleh seorang mempelai laki-laki kepada mempelai wanita.

Hikmah diwajibkannya mahar adalah menunjukkan pentingnya posisi akad ini, serta untuk memuliakan dan serta menghormati perempuan Islam. Juga memberikan dalil bagi pembinaan kehidupan perkawinan yang mulia bersamanya. Memberikan mahar dengan niat yang baik dengan maksud menggaulinya secara baik pula, demi kelangsungan pernikahan. Dengan adanya mahar, seorang perempuan dapat mempersiapkan semua perangkat perkawinan yang terdiri dari pakaian dan nafkah.

Besarnya ukuran mahar tidak ditetapkan dalam syariat Islam. Menurut Rahmat Hakim bahwa besar kecilnya mahar sangat bergantung pada kebiasaan negara maupun situasi dan kondisinya. Dengan demikian besarnya mahar yang diberikan oleh pihak laki kepada pihak perempuan itu berbeda-beda. Besar kecilnya jumlah mahar, jenis dan bentuknya hendaknya berpedoman pada sifat kesederhanaan dan ajaran kemudahan yang sesuai dengan anjuran syari'at Islam. Islam tidak menetapakan jumlahnya, tetapi sesuai dengan kemampuan pihak laki-laki dan keridhaan pihak perempuan. Mahar boleh berupa uang, perhiasan, perabot rumah tangga, binatang, jasa, harta perdagangan atau benda-benda yang mempunyai harga.

Dari pasal-pasal dalam Kompilasi Hukum Islam (KHI) dapat dipahami bahwa mahar merupakan kewajiban yang harus dibayar oleh calon suami kepada calon istrinya, baik secara kontan atau tidak kontan melalui persetujuan pihak calon istri. Jika pihak calon istri meminta mahar secara kontan maka wajib calon suami memberikan secara kontan kepada calon istri. Hak ini merupakan tanda bahwa mahar merupakan hak proregatif calon istri dalam menentukan jumlah dan jenisnya. Meskipun demikian, KHI menetapkan bahwa mahar dibayar atas dasar asas kesederhanaan yang sekiranya calon suami mampu melaksanakannya.

Walimah (الو ليمه) artinya Al-jam'u yaitu kumpul, sebab antara suami dan istri berkumpul, bagkan sanak saudara, kerabat, dan para tetangga. Walimah berasal dari kata Arab: الو لم artinya makanan pengantin, maksudnya adalah makanan yang disediakan khusus dalam acara pesta perkawinan. Bisa juga diartikan sebagai makanan untuk tamu undangan lainnya. ${ }^{12}$ Kata walimah diambil dari kata walm yang berarti pengumpulan karena suami dan istri berkumpul. Walimah adalah makanan dalam pesta pernikahan secara khusus. ${ }^{13}$

Hikmah dari diadakannya walimah al-ursy ini adalah dalam rangka memberikan pengumuman kepada halayak bahwa akad nikah sudah terjadi sehingga semua pihak masyarakat sudah mengetahui dan tidak akan ada tuduhan kepada mempelai laki-laki

12Tihami dan Sobari Sahrani, Fiqh Munakahat, Kajian Fikih Nikah Lengkap, Cetakan ke-1 (Jakarta:Rajawali, 2013) hal. 131

${ }^{13}$ Muhammad Sayyid Sabiq, Terjemahan Fiqih Sunnah, (Depok:Fathan Media Prima) hal.445

Jurnal Al-Ahwal Al-Syakhsiyyah : Jurnal Hukum Keluarga dan Peradilan Islam 5 
dan mempelai perempuan dikemudian hari. ${ }^{14}$ Dan juga ulama Malikiyah mengatakan terjadinya sebuah perkawinan itu lebih mengutamakan walimah dari menghadirkan dua orang saksi dalam akad perkawinan.

Kedudukan Hukum Adat dalam masyarakat

Adaik (adat) bagi masyarakat minangkabau adalah norma-noma, nilai-nilai aturan serta kebiasaan yang berkembang dan dikembangkan oleh masyarakatnya. Di masyarakat Minangkabau terdapat empat adat yang telah dilaksanakan secara turun temurun, yaitu ${ }^{15}$ :

a. Adat Nan Sabana Adat (adat yang sebenarnya)

Adat nan sabana adat ini adalah indak lakang dek paneh indak lapuak dek hujan indak lakang dek paneh (tidak lekang di panas, tidak lapuk di hujan) maksudnya segala sesuatu yang telah demikian terjadi menurut kehendak Allah SWT, jadi yang telah merupakan undang-undang alam yang selalu abadi dan tidak berubah-rubah. Adat nan sabana adat ini juga dimaksudkan segala sesuatu yang diterima Nabi Muhammad SAW menurut aturan yang terdapat di dalam Al-Qur'an atau disebut juga adat yang datang dari Allah SWT. Hal ini menunjukkan bahwa hukum adat dipengaruhi oleh ajaran keagamaan, segala sesuatunya dikuasai oleh Tuhan Yang Maha Esa.

\section{b. Adaik Istiadaik}

Adat istiadat ialah adat sebagai aturan (kaidah) yang telah ditentukan oleh leluhur Minangkabau yakni Datuak Katumanggungan dan Datuak Parpatiah nan Sabatang. Dalam hal ini adat mengandung arti kaidah-kaidah aturan yang berlaku tradisional sajak zaman nenek moyang hingga ke anak cucu sekarang. Aturan ini pada umumnya tidak mudah berubah.

\section{c. Adaik Nan Diadaikkan}

Maksudnya disini adalah adat kabiasaan yang ditetapkan atas dasar "bulat mufakat" para penghulu, tua-tua adat, cerdik pandai, dalam majelis kerapatan adat zaman dahulu atas dasar "halur" dan "patut". Sebagaimana sifat dari adaik nan di adakkan ini lain padang kain bilalang, lain lubuak lain ikannyo. Maksudnya adalah berbeda nagari berbeda pulalah adaik nan di adaikan berlaku di Nagari tersebut.

\section{d. Adaik Nan Taradaik}

Maksnudnya adalah kebiasaan berlingkah laku yang dipakai karena tiru meniru di antara anggota masyarakat.

Adapun hasil penelitian adalah: Sistem Perkawinan di Nagari Situjuah Gadang, Kecamatan Situjuah Limo Nagari, Kabupaten Lima Puluh Kota, Provinsi Sumatera Barat. Sistem perkawinan Minangkabau merupakan hasil budaya masyarakat Minangkabau itu sendiri dimana tatacara sesuai dengan adat daerah setempat. Tata

\footnotetext{
${ }^{14}$ Amir Syarifuddin, Garis-gariS Besar Figh, Cetakan ke-2. ( Jakarta:Kencana, 2003), hal.118

${ }^{15}$ Hilman Adikusuma, Pengantar Ilmu Hukum Adat Indonesia, Cetakan ke 2. (Bandung:Mandar Maju,1995),hal. 10

6 Jurnal Al-Ahwal Al-Syakhsiyyah : Jurnal Hukum dan Peradilan Islam
} 
Annisa Ummulhusni, Siti Nurfatoni, Uang SASUDUIK dalam Sistem Perkawinan di Nagari Situjauh pelaksanaan perkawinan menurut orang Minangkabau ada dua yaitu tata cara menurut agama dan tata cara menurut adat istiadat. Walaupun seseorang sudah melangsungkan akad nikah menurut syara', namun mereka belum boleh berkumpul bersama apabila rangkaian adat selasai dilalui.

Pelaksanaan perkawinan di Nagari Situjuah Gadang, Kecamatan Situjuah Limo Nagari, Kabupaten Lima Puluh Kota, Provinsi Sumatera barat berikut tahapan pelaksanaan perkawinan yang harus dilalui antara lain sebagai berikut: marosok-rosok, manapiak bandua (lamaran/pinangan), upacara pernikahan, manjalang mintuo. ${ }^{16}$

1. Marosok-rosok

Ketentuan di Nagari Situjuah Gadang hal yang dilakukan pertama seblum pinangan adalah marosok-rosok. Marosok-rosok merupakan seorang laki-laki yang ingin melamar si gadis tersebut menyuruh seseorang yang dipercayainya (informan) untuk menanyakan kepada pihak perempuan tentang maksudnya untuk memperistri si gadis dan apakah gadis tersebut sudah menjadi pinangan orang lain.

Dalam konsep hukum Islam marosok-rosok bagi masyarakat di Nagari Situjuah Gadang Kecamatan Situjuah Limo Nagari Kabupaten Lima Puluh Kota Provinsi Sumatera Barat bukan termasuk lamaran/khitbah namun merupakan proses menuju khitbah/lamaran.

\section{Manapiak Bandua (Pinangan/Lamaran)}

Setelah beberapa hari dari orang yang mencari tau mengenai penelusuran tentang kesediaan di calon, maka beberapa hari setelah itu datang lah 2 atau 3 orang utusan ke rumah orang tau si gadis dalam rangka Manapiak Bandua atau disebut juga lamaran adat. Utusan yang datang biasanya mamak dan bapo yang pintar pesembahan. Menanggapi dari keinginan pihak laki-laki tersebut maka pihak mamak si gadis menerima lamaran tersebut. Dan acara selanjutnya adalah "tuka tando", tuka tando dimana laki-laki memberikan sebuah cincin kepada tunangannya, oleh karena itu pada saat tuka tando perempuan harus hadir, namun jikalau sakit boleh diwakilkan dengan walinya.

Setelah itu, kedua belah pihak manukuak hari pernikahan dan hari baralek. Dalam proses ini, mamak dari pihak perempuan menyampaikan maksud dari pihak perempuan untuk membacakan penetapan jumlah uang sasuduik yang harus dipenuhi oleh laki-laki. Uang sasuduik yang akan diserahkan oleh laki-laki terhadap pihak perempuan harus diketahui dan disepakati terlebih dahulu oleh niniak mamak (ninik mamak) dari pihak perempuan, hal tersebut dilakukan dengan cara bermusyawarah untuk menetapkan suatu kemufakatan.

${ }^{16}$ Wawancara dengan salah seorang tokoh adat di Nagari Situjuah Gadang, Kecamatan Situjuah Limo Nagari, Kabupaten Lima Puluh Kota, Provinsi Sumatera Barat yaitu Datuak Rajo Malano Mudo pada tanggal 05 April 2019 Pukul 10:00

Jurnal Al-Ahwal Al-Syakhsiyyah : Jurnal Hukum Keluarga dan Peradilan Islam 7 
Uang sasuduik adalah pemberian yang diharuskan kepada laki-laki yang akan melangsungkan pernikahan yaitu dengan memberikan sejumlah uang yang diinginkan oleh calon istri dan pihak keluarganya. Uang sasuduik ini disepakati terlebih dahulu oleh niniak mamak (ninik mamak) pihak perempuan. Karena yang berhak menentukan jumlah uang sasuduik adalah niniak mamak pihak perempuan baru setelah itu disepakati oleh kedua orang tua perempuan. ${ }^{17}$

Dalam hal ini ketentuan adat dalam penyerahan uang sasuduik adalah pihak perempuan atau niniak mamak dari pihak perempuan akan merundingkannya bersama orang tua perempuan dan kerabat lainnya berapa jumlah uang sasuduik yang harus dipenuhi laki-laki. Setelah kesepakatan tersebut disepakati maka niniak mamak dari pihak perempuan memutuskan jumlah uang sasuduik tersebut. Apabila laki-laki keberatan maka laki-laki tersebut akan meminta pengurangan berdasarkan kemampuannya, namun harus berdasarkan kesepakatan dari pihak perempuan dalam hal ini niniak mamak dan orang tua perempuan.

Jarak antara pinangan dengan penyerahan uang sasuduik adalah tergantung kesepakatan kedua belah pihak, namun tidak melewati batas untuk menuju akad nikah dan baralek itu sendiri. Apabila laki-laki lalai dalam memenuhi kesepakatan tersebut pihak perempuan atau niniak mamak akan menunda perkawinan hingga laki-laki tersebut mampu membayarkan uang sasudui berdasarkan kesepakatan diawal. Setelah penundaan tersebut niniak mamak atau pihak perempuan melaporkan ke kantor Kerapatan Adat Nagari (KAN) dalam hal ini kepada Ketua Kerapatan Adat Nagari. Karena dalam proses penetapan jumlah uang sasuduik tersebut hingga penetapan tanggal perkawinan tokoh adat datang menghadiri. ${ }^{18}$

Namun, ketika telah terjadi penundaan laki-laki masih saja lalai dalam pemenuhan uang sasuduik maka akan terjadi pembatalan karena dari sanalah niniak mamak dari pihak perempuan melihat bahwa si laki-laki belum bisa mengemban rumah tangga. ${ }^{19}$

Menurut hukum Islam manapiak bandua sudah sesuai dengan khitbah/lamaran/pinangan karena dalam Kompilasi Hukum Islam Pasal 1 point a, peminangan adalah kegiatan-kegiatan ke arah terjadinya hubungan perjodohan antara seorang pria dengan seorang wanita.

${ }^{17}$ Wawancara dengan salah seorang pengurus Kerapatan Adat Nagari (KAN) Nagari Situjuah Gadang, Kecamatan Situjuah Limo Nagari, Kabupaten Lima Puluh Kota, Provinsi Sumatera Barat,yaitu Datuak Bandaro Putiah pada tanggal 09 April Pukul 09:00 WIB

${ }^{18}$ Wawancara dengan salah seorang pengurus Kerapatan Adat Nagari (KAN) Nagari Situjuah Gadang, Kecamatan Situjuah Limo Nagari, Kabupaten Lima Puluh Kota, Provinsi Sumatera Barat,yaitu Datuak Bandaro Putiah pada tanggal 9 April Pukul 10:00 WIB

${ }^{19}$ Wawancara dengan salah seorang pengurus Kerapatan Adat Nagari (KAN) Nagari Situjuah Gadang, Kecamatan Situjuah Limo Nagari, Kabupaten Lima Puluh Kota, Provinsi Sumatera Barat,yaitu Datuak Bandaro Putiah pada tanggal 9 April Pukul 10:00 WIB

8 Jurnal Al-Ahwal Al-Syakhsiyyah : Jurnal Hukum dan Peradilan Islam 
Annisa Ummulhusni, Siti Nurfatoni, Uang SASUDUIK dalam Sistem Perkawinan di Nagari Situjauh

3. Upacara Pernikahan

Biasanya pelaksanaan akad nikah terlebih dahulu di Mesjid Nagari. Setelah pelaksanaan akad nikah maka marapulai (pengantin laki-laki) dihantarkan oleh mamak dan orang tua dari pihak laki-laki ke rumah anak daro (pengantin perempuan) dengan cara arak-arakan dalam hal ini disebutkan ulua anta anta sarah tarimo penganten. Maksudnya adalah mempelai pria diantar ke rumah mempelai wanita dan disambut meriah oleh keluarga pihak wanita, acara ini dinamakan manjapuik marapulai. Dalam acara ini, juga para tokoh adat, niniak mamak menyampaikan pepatah adat yang berisikan nasihat-nasihat dalam berumah tangga. Sementara itu di rumah anak daro telah disiapkan baralek / pesta pernikahan, rumah dan kamar dihiasai sedemikian indahnya. Karena dalam acara pernikahan di Minangkabau baralek adalah inti dari semua prosesi pernikahan. Disana sudah berdiri marawa (pertanda adanya hajatan) khas Minangkabau.

Dalam adat upacara pernikahan ini yang menjadi daya tarik orang minang adalah hiasan kamar pengantin di hias begitu indah dan dalam baralek/ pesta pernikahannya seluruh rumah dihiasi dan dihidangkan makanan daerah tersebut. Uang sasuduik tersebut digunakan untuk mengisi kamar pengantin tersebut serta hiasannya dan juga digunakan untuk acara baralek tersebut. ${ }^{20}$

Dalam hukum Islam pernikahan harus terpenuhi rukun dan syarat. Setelah terpenuhi rukun dan syarat maka akan terjadi pernikahan tersebut dan sah. Setelah pernikahan sah, maka akan ada walimatul 'ursy yang mana baralek disebut masyarakat Minangkabau. Barelak telah sesuai dengan ajaran syara' sebagaimana hadist nabi yang artinya umumkanlah olehmu akan pernikahan.

\section{Manjalang Mintuo}

Setalah diadakannya pernikahan dan baralek keesokan harinya akan ada manjalang mintuo. Manjalang mintuo adalah pihak perempuan datang kerumah pihak laki-laki dengan membawa serantang makanan untuk makan malam, dengan tujuan mempererat hubungan kedua keluarga tersebut. Karena perkawinan bukan saja mengawinkan dua insan yang berlainan namun juga mempersatukan kedua keluarga besar.

\section{Asal-usul dan Keududukan Uang Sasuduik dalam Sistem Perkawinan di Nagari Situjuah Gadang}

Asal-usul pemberian uang sasuduik di Nagarian Situjuah Gadang dalam perkawinan sudah terjadi sejak dari zaman dahulu yang ditetapkan oleh tetua adat dahulu

\footnotetext{
${ }^{20}$ Wawancara dengan salah seorang tokoh adat di Nagari Situjuah Gadang, Kecamatan Situjuah Limo Nagari, Kabupaten Lima Puluh Kota, Provinsi Sumatera Barat yaitu Datuak Rajo Malano Mudo pada tanggal 05 April 2019 Pukul 10:00
}

Jurnal Al-Ahwal Al-Syakhsiyyah : Jurnal Hukum Keluarga dan Peradilan Islam 9 
kala dan berlaku hingga sekarang. Karena pemberian uang sasuduik merupakan salah satu adat di Nagari Situjuah Gadang tidak bisa dilepaskan begitu saja. ${ }^{21}$

Di Nagari Situjuah Gadang seseorang laki-laki diharuskan memberikan uang sasuduik dan harus terpenuhinya uang sasuduik kepada pihak perempuan tujuannya adalah sebagai berikut:22

a. Untuk memperilihatkan dan menyatakan bahwa laki-laki tersebut siap mengemban tanggung jawab berumah tangga terhadap istrinya dan anaknya kelak.

b. Untuk pemenuhan kamar pengantin (paisi biliak).

c. Untuk membantu baralek/ pesta pernikahan, karena baralek merupakan salah satu prosesi adat yang tidak boleh ditinggalkan dan ketika baralek kamar pengantin di rias dan akan dibuka lebar guna lihat oleh tamu undangan yang datang.

Uang sasuduik dalam perkawinan ini sebenarnya tidak akan membatalkan akad nikah, namun dikarenakan perkawinan adat dan perkawinan syara' merupakan serangkaian yang tidak bisa dipisahkan makanya uang sasuduik dapat menunda hingga ada yang batal perkawinan. Karena dari uang sasuduik piha perempuan bisa melihat kesiapan seorang laki-laki dalam berumah tangga, mampu mengemban tanggung jawab dalam menjalin rumah tangga. Dan juga uang sasuduik ini harus diberikan kepada pihak perempuan yang berguna untuk pengisi kamar pengantin dengan memenuhi selaruh peralatan kamar dan digunakan untuk baralek/ pesta pernikahan. ${ }^{23}$

Di Kanagarian Situjuah Gadang Kecamatan Situjuah Limo Nagari Kabupaten Lima Puluh Kota Provinsi Sumatera Barat ini pernikahan menurut adat adalah baralek, karena ditinjau dari segi sosial masyarakat Minangkabau seseorang dikatakan telah menikah ketika baralek/ pesta pernikahan itu terlaksana. Keharusan memberikan uang sasuduik ini dalam istilah minang "kok indak panuah ka ateh panuah ka bawah" maksudnya adalah kalau tidak bisa terpenuhi jumlah awal dari uang sasuduik ini untuk baralek besar-besaran, maka boleh melakukan musyawarah kembali untuk menentukan berapa

${ }^{21}$ Wawancara dengan salah seorang pengurus Kerapatan Adat Nagari (KAN) Nagari Situjuah Gadang, Kecamatan Situjuah Limo Nagari, Kabupaten Lima Puluh Kota, Provinsi Sumatera Barat, yaitu Datuak Bandaro Putiah pada tanggal 6 Juli 2019 Pukul 20:20

${ }^{22}$ Wawancara dengan salah seorang tokoh adat di Nagari Situjuah Gadang, Kecamatan Situjuah Limo Nagari, Kabupaten Lima Puluh Kota, Provinsi Sumatera Barat yaitu Datuak Rajo Malano Mudo pada tanggal 06 April 2019 Pukul 09:00

${ }^{23}$ Wawancara dengan salah seorang tokoh adat di Nagari Situjuah Gadang, Kecamatan Situjuah Limo Nagari, Kabupaten Lima Puluh Kota, Provinsi Sumatera Barat yaitu Datuak Rajo Malano Mudo pada tanggal 05 April 2019 Pukul 09:00

10 Jurnal Al-Ahwal Al-Syakhsiyyah : Jurnal Hukum dan Peradilan Islam 
Annisa Ummulhusni, Siti Nurfatoni, Uang SASUDUIK dalam Sistem Perkawinan di Nagari Situjauh

kesanggupan pihak laki-laki dalam membayar uang sasuduik untuk mengadakan baralek kecil-kecilan saja namun ini harus ada tidak boleh tidak ada. ${ }^{24}$

Pemenuhan uang sasuduik ini merupakan bagian dari adaik nan di adaikan ${ }^{25}$. Ini sesuaia dengan pembahasan di Bab sebelumnya karena uang sasuduik merupakan adat kebiasaan yang ditetapkan atas dasar "bulat mufakat" para penghulu, tua-tua adat, cerdik pandai, dalam majelis kerapatan adat zaman dahulu atas dasar "halur" dan "patut". Ketentuan ini dapat berubah menurut keadaan tempat dan waktu. Sebagaimana sifat dari adat yang di adatkan ini lain padang kain belalang, lain lubuk lain ikannya dan uang sasuduik ini hanya berlaku di Nagari Situjuah Gadang Kecamatan Situjuah Limo Nagari Kabupaten Lima Puluh Kota Provinsi Sumatera Barat. ${ }^{26}$

\section{Tinjauan Hukum Islam terhadap Pemberian Uang Sasuduik bagi Laki-laki yang Akan Melangsungkan Perkawinan di Nagari Situjuah Gadang}

Hukum perkawinan Islam menjelaskan pemberian yang wajib diberikan kepada perempuan disaat pernikahan adalah mahar bukan uang sasuduik, sebagaimana terdapat didalam kompilasi Hukum Islam (KHI) Pasal 30 "calon mempelai pria wajib membayar mahar kepada calon mempelai wanita yang jumlah, bentuk dan jenisnya disepakati oleh kedua belah pihak". Dalam pemberian mahar tidak ada ketentuan hukum yang disepakati oleh para ulama tentang berapa batas maksimal dan minumumnya. Yang jelas mahar wajib ditunaikan.

Bagi masyarakat di Nagari Situjuah Gadang hingga saat ini adat tersebut masih dipertahankan karena di Nagari Situjuah Gadang ini merupakan adat yang sudah dari dahulu. Walaupun tidak ada dalam anjuran Islam, namun sebagai masyarakat adat kita harus menghargai dan melanjutkan adat yang sudah berlaku sedari dahulu, kita harus menjaga dan melestarikan untuk generasi selanjutnya, asalkan uang sasuduik ini tidak memberatkan dan menyulitkan semua pihak.

Adat ('adah), dalam bahasa Arab kata 'adah merupakan sinonim dari kata 'urf. Secara literal, kata 'adah berarti kebiasaan, adat atau prakter, sementara arti kata 'urf adalah "sesuatu yang telah diketahui". 'Urf terdiri dari dua macam dari segi ruang lingkup penggunaannya:

${ }^{24}$ Wawancara dengan salah seorang tokoh adat di Nagari Situjuah Gadang, Kecamatan Situjuah Limo Nagari, Kabupaten Lima Puluh Kota, Provinsi Sumatera Barat yaitu Datuak Rajo Malano Mudo pada tanggal 05 April 2019 Pukul 09:00

${ }^{25}$ Wawancara dengan salah seorang pengurus Kerapatan Adat Nagari (KAN) Nagari Situjuah Gadang, Kecamatan Situjuah Limo Nagari, Kabupaten Lima Puluh Kota, Provinsi Sumatera Barat, yaitu Datuak Bandaro Putiah pada tanggal 6 Juli 2019 Pukul 20:20

${ }^{26}$ Wawancara dengan salah seorang pengurus Kerapatan Adat Nagari (KAN) Nagari Situjuah Gadang, Kecamatan Situjuah Limo Nagari, Kabupaten Lima Puluh Kota, Provinsi Sumatera Barat, yatitu Datuak Bandaro Putiah pada tanggal 9 April Pukul 10:00 WIB 
a) 'Urf umum عرف عام yaitu kebiasaan yang telah umum berlaku dimanamana, hampir diseluruh penjuru dunia, tanpa memandang negara, bangsa dan agama.

b) 'Urf khusus / عرف خاصyaitu kebiasaaan yang dilakukan sekelompok orang ditempat tertentu atau di waktu tertentu, tidak berlaku di semua tempat dan disembarangan waktu.

'Urf terdiri dari segi baik buruknya:27

a. 'Urf sahih / عرف صحيح yaitu kebiasaan yang dilakukan manusia, tidak bertentangan dengan dalil syara', tidak menghalalkan yang haram tidak mengbatalkan yang wajib.

b. 'Urf fasid / عرف فاسد yaitu kebiasaan yang dilakukan oleh manusia tetapi bertentang dengan syara'.

Bagi masyarakat di Nagari Situjuah Gadang pemberian uang sasuduik ini merupakan suatu bentuk keseriusan dan kesiapan seorang laki-laki untuk menikahi seorang perempuan yang dia inginkan dan sebagai pengisi kamar hingga baralek. Pemberian wajib dalam hukum perkawinan Islam hanyalah mahar, sehingga jika ada pemberian lain dalam hal ini uang sasuduik maka itu disebut hadiah dan hal ini di anjurkan sebagaimana hadis Nabi SAW yang diriwayatkan oleh Abu Hurairah ra: تها دوا تحا بوا لهi "Saling memberi hadiahlah kalian, niscaya kalian akan saling mencintai" 28

Hadits ini menerangkan bahwa dengan saling memberikan hadiah maka hal itu dapat menyatukan hati dan menguatkan ikatan cinta antara sesama manusia, karena pada dasarnya manusia memang sangat suka jika diberi suatu hadiah, baik berupa hadiah barang ataupun uang. Apalagi hadiah ini diberikan untuk pernikahan calon istri akan merasa sangat senang sekali.

Penggunaan adat pemberian uang sasuduik dalam perkawinan yang berada di Nagari Situjuah masuk kepada 'Urf yang bersifat perbuatan, yaitu kebiasaan masyarakat yang saling pengertian dan meridhoi (diantara orang yang memberikan uang sasuduik dan orang yang menerimanya). Dilihat dari cakupannya uang sasuduik merupakan 'Urf khas/ khusus yaitu kebiasaan yang berlaku khusus di daerah tertentu, dalam hal ini di Nagari Situjuah Gadang, Kecamatan Situjuah Limo Nagari, Kabupaten Lima Puluh Kota, Provinsi Sumatera Barat. Sedangkan dilihat dari keabsahannya, maka pada dasarnya bisa dikatakan 'urf shahih karena dalam pemenuhan uang sasuduik ini mendatangkan kemaslahatan dengan terpenuhinya paisi biliak dan terlaksanakannya baralek.

27 Abdul Wahab Khallaf, Ilmu Ushul Fikih Kaidah Hukum Islam. (Jakarta: Pustaka Amani, 2002) hal.

28 Sayyid Sabiq, Fiqih Sunnah Jilid 3, diterjemahan oleh Abu Syauqina Lc dan Abu Aulia Rahma Lc, Cetakan ke 2 (Jakarta: Tina Badi Gemilang,2013), hal. 450

12 Jurnal Al-Ahwal Al-Syakhsiyyah : Jurnal Hukum dan Peradilan Islam 
Annisa Ummulhusni, Siti Nurfatoni, Uang SASUDUIK dalam Sistem Perkawinan di Nagari Situjauh

\section{SIMPULAN}

Berdasarkan penelitian yang telah dilakukan mengenai Uang Sasuduik dalam sistem perkawinan di Nagari Situjuah Gadang Kecamatan Situjuah Limo Nagari Kabupaten Lima Puluh Kota Provinsi Sumatera Barat, maka dapat ditarik kesimpulan bahwa sistem perkawinan di Nagari Situjuah Gadang Kecamatan Situjuah Limo Nagari Kabupaten Lima Puluh Kota Provinsi Sumatera Barat memiliki perpaduan antara sistem perkawinan Islam dan sistem perkawinan adat. Sistem perkawinan Islam dengan terpenuhinya rukun dan syarat perkawinan dan teknisnya menggunakan sistem perkawinan adat. Tahapan dari sistem perkawinan adat di Nagari Situjuah Gadang Kecamatan Situjuah Limo Nagari Kabupaten Lima Puluh Kota Provinsi Sumatera Barat adalah marosok-rosok, manapiak bandua, upacara perkawinan dan manjalang mintuo.

Asal usul uang sasuduik dalam sistem perkawinan di Nagari Situjuah Gadang Kecamatan Situjuah Limo Nagari Kabupaten Lima Puluh Kota Provinsi Sumatera Barat adalah pemberian yang sudah terjadi sejak dari zaman dahulu yang ditetapkan oleh tetua adat dahulu kala dan berlaku hingga sekarang. Kedudukan uang sasuduik dalam perkawinan di Nagari Situjuah Gadang Kecamatan Situjuah Limo Nagari sebagaimana "kok indak panuah ka ateh panuah ka bawah" maksunya pemenuhan uang sasuduik ini kalau tidak sanggup mengisi ke atas maka mengisi ke bawah. Kedudukannya ini merupakan keharusan adat dan merupakan bagian dari adaik nan diadaikan.

Tinjauan hukum Islam terhadap pemberian uang sasuduik dalam perkawinan di Nagari Situjuah Gadang Kecamatan Situjuah Limo Nagari Kabupaten Lima Puluh Kota Provinsi Sumatera Barat merupakan ketentuan tambahan yang diberlakukan di daerah ini bukanlah ketentuan yang termasuk kedalam kategori Islam/syara'. Uang sasuduik dapat berlaku ketika menimbulkan kemaslahatan. Dalam hukum Islam pemberian uang sasuduik dikategorikan dalam 'urf khas yang shahih dan sebagaimana dalam hadis nabi riwayat Abu Hurairah pemberian uang sasuduik dapat dikategorikan sebagai hadiah "saling memberi hadiahlah kalian, niscaya kalian akan saling mencintai".

\section{DAFTAR PUSTAKA}

Abdul Rahman Ghozali, Fiqh Munakahat, Cet ke-1 Jakarta: Kencana, 2003.

Abdul Wahab Khallaf, Ilmu Ushul Fikih Kaidah Hukum Islam. Jakarta: Pustaka Amani, 2002.

Bahrun Abubakar dan Hery Noer Aly, Terjemah Tafsir Al-Maraghi Juz 4, Semarang: Karya Toha Putra, 1993.

Kompilasi hukum Islam, Bandung: Fokusindo Mandiri, 2016. 
Volume I, Nomor 1, Maret 2020

Amir Syarifuddin, Hukum Perkawinan Islam di Indonesia antara Fiqh Munakahat dan Undang-undang Perkawinan, Cet ke-3. Jakarta: Kencana, 2009

Kementrian Agama Republik Indonesia, Al-Qur'an dan Terjemah. Bandung: Diponegoro, 2012

Sayyid Sabiq, Fiqih Sunnah Jilid 3, diterjemahan oleh Abu Syauqina Lc dan Abu Aulia Rahma Lc, Cetakan ke 2. Jakarta: Tina Badi Gemilang,2013. 